\title{
Jordan's Self-Fulfilling Prophecy: The Production of Feeble Political Parties and the Perceived Perils of Democracy
}

\begin{abstract}
This article analyzes the depiction of political parties in a "hybrid regime" so as to explain how state-sponsored articulatory practices contribute to the discrediting of potential opponents. Through an examination of textbooks, speeches and government documents combined with semi-structured interviews and participant observation, it dissects how tropes concerning party weakness or extremism make Jordan appear unprepared for democracy. Making the legal opposition seem menacing or incompetent helps the Hashemite regime legitimize the haphazard pace of political reforms. It is a crucial strategy through which the monarchy maintains the backing or tepid compliance of foreign and local supporters. Yet still, the discursive features of authoritarianism, in Jordan and elsewhere, continue receiving short thrift. Far from epiphenomenal, the monarchy's discursive practices shape the conceptual universe and institutional contexts in which politics takes place.
\end{abstract}

\section{Keywords}

Jordanian politics, democratization, authoritarianism, discourse, hegemony 
Prior to the events now remembered as the Arab Spring, Jordan was frequently classified as a 'hybrid regime.' ${ }^{1}$ The Hashemite Kingdom was deemed an 'authoritarian monarchy,' 'liberal autocracy' or 'pseudo-democracy,' never quite fitting neatly into the typologies so beloved in the democratization literature. ${ }^{2}$ Along with Egypt, Morocco and Tunisia, Jordan adopted various formal institutions commonly associated with liberal democracy, yet to little avail. Monarchical rule persisted, although its institutional façade was transformed. Today, the Hashemite Kingdom is frequently praised as a paragon of stability and prudent reform. Continuity in rule and minimal social unrest offer a soothing contrast to the chaos that engulfs its neighbors. Foreign allies praise the country's king, international organizations commend the regime's commitment to democratization, while many Jordanian politicians accept the limits placed on participation as prudent and necessary. ${ }^{3}$ The intermittent external pressures to democratize have faded; the fluctuations of geopolitics have downgraded the importance of political reform. As one prominent Washington commentator stated recently, 'the survival of the Hashemite regime is a U.S. strategic imperative. ${ }^{4}$ The perils of regional instability, rising extremism and an untrustworthy opposition make public participation appear an unwarranted risk. Interestingly, government officials and Palace spokespeople continue to

\footnotetext{
${ }^{1}$ Curtis R. Ryan and Jillian Schwedler, 'Return to Democratization or New Hybrid Regime?' Middle East Policy 11.2 (2004), pp. 138-151.

2 Daniel Brumberg, 'The Trap of Liberalized Autocracy', Journal of Democracy 13.4 (2002), pp. 56-68; Russell E. Lucas, 'Monarchical Authoritarianism: Survival and Political Liberalization in a Middle Eastern Regime Type', International Journal of Middle East Studies 36.1 (2004), pp. 103-119; Frédéric Volpi, 'Pseudo-Democracy in the Muslim world', Third World Quarterly 25.6 (2004), pp. 1061-1078.

${ }^{3}$ Morten Valbjørn, 'The 2013 Parliamentary Elections in Jordan. Three Stories and Some General Lessons', Mediterranean Politics 18.2 (2003), pp. 311-317.

${ }^{4}$ David Schenker, 'Saving Jordan's King Abdullah Must be a U.S. Priority', The Wall Street Journal, March 20, 2013, http://online.wsj.com/news/articles/SB10001424127887323829504578267951332697058 (accessed 4 April 2014).
} 
emphasize the Hashemite regime's commitment to political reform to audiences at home and abroad. King Abdullah II is an expert in this regard. An authoritarian incumbent who quickly learned the vocabulary of international expectations, he has fully adopted the rhetoric of democratization. ${ }^{5}$ In addition to generating foreign support for the monarchy, this rhetoric has been a key weapon in the Palace's domestic political arsenal; it functions as the never-ending soundtrack of Jordanian politics. Taken at face value, the monarchy appears not only interested but also committed to implementing free and fair elections, a multi-party system and representative parliamentary government. As Schwedler points out, 'these concepts are often left poorly defined, though they are frequently invoked.' 6 Despite this conceptual ambiguity, key actors exert considerable and consistent effort to publicize the regime's democratizing pretensions. Yet still, Jordanian politics is rarely pondered in relation to these non-institutional forms of power. The discursive features of authoritarianism receive short thrift.

To remedy this lacuna, this article explores the monarchy's portrayal of partisan life in Jordan to illustrate how it shapes one key political debate in the country. It draws upon Laclau and Mouffe's theory of discourse, defined as a horizon of 'multifarious practices, meanings and conventions...through which a certain sense of reality and understanding of society are constituted, ${ }^{7}$ to scrutinize the power relations and strategies through which the Hashemite regime attempts to fix meaning within a particular domain.

\footnotetext{
${ }^{5}$ Holger Albrecht, and Oliver Schlumberger. "Waiting for Godot": Regime Change without Democratization in the Middle East', International Political Science Review 25.4 (2004), pp. 371392.

${ }^{6}$ Jillian Schwedler, Faith in Moderation: Islamist parties in Jordan and Yemen (Cambridge University Press, 2006), p. 3.

${ }^{7}$ as quoted in Aletta J. Norval, Deconstructing Apartheid Discourse (London: Verso, 1996), p. 2; Ernesto Laclau, and Chantal Mouffe, Hegemony and Socialist Strategy: Towards a Radical Democratic Politics (New York: Verso, 2001), p.112.
} 
Specifically, it examines the articulation of a key nodal point (democracy) that provisionally binds together a particular web of meanings and privileged signifiers (political parties, reform and opposition) at the heart of the monarchy's legitimating discourse. ${ }^{8}$ It does so through a heuristic analysis of the Palace's depiction of partisan life and opposition politics so as to explore the persistent assumptions, themes and vocabularies that shape, enable and constrain the country's political reform debate. I follow Andrea Teti's call to approach democratization as a discourse and a category of action in its own right by focusing on the "processes through which what counts as knowledge is produced and deployed in policy-making and practice.'9

In more than one hundred interviews $(=117)$ conducted during 14 months of fieldwork in Jordan (2013-2014), party weakness or extremism was consistently emphasized during discussions of the political reform process. The majority of those queried referenced surveys indicating low party membership, highlighted the dogmatic beliefs of certain groups, or underscored the incapacity of organized political forces. Even organizations and citizens critical of the regime's democratization efforts frequently echoed the monarchy's rhetoric, citing party incapacity or radicalism as a chief obstacle to political reform. Why do political parties remain inconsequential despite the monarchy's rhetorical commitment to strengthening them? How do different actors relate to the Palace's portrayal of Jordan's political groups and what political impact does this engender? Coupled with the abovementioned interviews, I explored these questions by observing seven different NGO-sponsored conferences and seminars in which various

\footnotetext{
${ }^{8}$ Stressing the partial character of this discursive fixation implies the impossibility of any final closure of signification, which is why hegemonic formations are neither permanent nor fixed. Laclau and Mouffe, Hegemony and Socialist Strategy, p. 113.

${ }^{9}$ Andrea Teti, 'Beyond Lies the Wub: The Challenges of (Post) Democratization', Middle East Critique 21.1 (2012), p. 7.
} 
elements of political reform and partisan life were discussed (party capacity building, electoral laws, decentralization). This allowed a more detailed understanding of Jordanian party politics from the perspective of its key participants. In addition, I compiled introductory university textbooks in history, civics and politics and official Palace documents (speeches, press releases, working papers) to re-construct the official position. This combination helped capture the regime's portrayal of democratization, trace the mechanisms for its diffusion while analyzing its impact. The article will argue that narratives emphasizing party weakness or extremism work to make Jordan appear as simply not ready for parliamentary democracy. These tropes are more than just an ideology meant to foster false consciousness or acquiesce foreign donors; they comprise a set of 'practices that systematically form the objects of which they speak.' ${ }^{10}$ Party weakness and extremism are, in many respects, a self-fulfilling prophecy.

The article proceeds in four parts. It begins by outlining the contours of hegemonic depictions of Jordanian political parties before assessing prevalent methods used to study these dynamics. I critique the democratization literature's consistent disregard for non-institutional forms of power, a form of 'statolatry' that views the state as a fixed entity whose actions and effects are limited to formal institutions. ${ }^{11}$ The following section summarizes Jordanian political reforms and developments since 1989. The third section dissects regime-sponsored rhetoric regarding Jordan's political parties. It outlines both their deployment by authoritarian elites as well as their adoption by key

\footnotetext{
${ }^{10}$ Michel Foucault, The Archaeology of Knowledge, trans. Alan Sheridan Smith (New York: Pantheon Books, 1972), p. 49.

${ }^{11}$ Antonio Gramsci, Selections from the Prison Notebooks of Antonio Gramsci, trans. and ed. Q. Hoare and G. Smith (New York: International Publishers, 1971), pp. 268-69. For more on Gramsci's critique of liberal conceptions of politics, see Adam David Morton, Unraveling Gramsci: Hegemony and Passive Revolution in the Global Political Economy (London: Pluto Press, 2007), pp. 88-91.
} 
local and foreign actors. The essay concludes by expanding on its main theoretical and empirical insights, teasing out the importance of discursive practices to autocratic rule. The Contingent Truths of Partisan Life

'One should stress the importance and significance which, in the modern world, political parties have in the elaboration and diffusion of conceptions of the world, because essentially what they do is to work out the ethics and the politics corresponding to these conceptions and act as it were as their historical "laboratory"., 12

Party frailty and extremism stand foremost among the pretexts deployed by the Jordanian monarchy to implicitly legitimize haphazard political reforms. For former Minister of Political Development, current Senator and one-time member of Jordan's illegal opposition, Musa Maaytah, gradual change is the only way forward: 'We have no tradition of democratic life in Jordan. We must build it slowly, with the King leading the reforms and ensuring stability. ${ }^{13}$ For Maaytah, 'the current parties are a mess, how can we democratize when we have such weak political organizations? ${ }^{14}$ Unsurprisingly, current members of the royally appointed Cabinet feel similarly. When pressed on possible amendments to the King's constitutional powers in early 2013, Prime Minister Abdullah Ensour stated that, 'We are not currently ready to amend the King's powers in the Constitution because the democratic process in Jordan has only just begun, and partisan life has not yet reached maturity., ${ }^{15}$ By depicting the opposition as menacing, incompetent or unprepared, the regime compels foreign allies and international

\footnotetext{
${ }^{12}$ Gramsci, Selections from the Prison Notebooks, p. 335.

${ }^{13}$ Interview with Engineer Musa Maaytah (Former Minister of Political Development and current Senator), Amman, Jordan, 27 April 2014.

${ }^{14}$ Ibid.

${ }^{15}$ Tamer al-Samadi, 'Jordan's Prime Minister: King will Delegate some Powers', trans. Pascale Menassa Al-Hayat January 18, 2013, http://www.al-monitor.com/pulse/politics/2013/01/kingpowers-king.html\#ixzz3BgqZZFgQ (accessed 25 August 2014).
} 
organizations to fear potential instability in a country whose geopolitical importance need not be reiterated. Such portrayals compel members of the Jordanian bourgeoisie to ponder the economic turmoil and violence that has accompanied political unrest in neighboring Iraq, Egypt and Syria. They also prompt ordinary citizens to consider the monarchy as the guarantor, rather than a prime obstacle, to popular participation. Over time, the meanings the Palace has assigned to political parties have assumed 'the fanatical granite compactness of "popular beliefs" which assume the same energy as "material forces". 16 Their impact is tangible. According to one survey conducted by an independent Jordanian NGO in $2012,98 \%$ of Jordanians are not affiliated with any political party, while only $30 \%$ have some knowledge of the parties that exist within the country. ${ }^{17}$ Only $34 \%$ believed parties would play an important role in the 2013 parliamentary elections.

In explaining the persistence of monarchical rule in Jordan, prevalent approaches emphasize the importance of institutional arrangements and strategies in structuring choices made by members of the opposition, businessmen and the military. ${ }^{18}$ Other recent works highlight the significance of external support and economic liberalization, along with the pathways through which they bolster Jordan's ruling elite and the coalitions

\footnotetext{
${ }^{16}$ Antonio Gramsci, Selections from the Prison Notebooks, p. 404.

${ }^{17}$ Al-Hayat Center, Final Report on the Monitoring of the 2013 Jordanian Parliamentary Elections (Amman: Al-Hayat Center for Civil Society Development, 2013), http://www.hayatcenter.org/publications/final-report-on-monitoring-jordans-2013-parliamentaryelections/ (accessed 3 April 2014).

${ }^{18}$ Russell E. Lucas, Institutions and the Politics of Survival in Jordan: Domestic Responses to External Challenges, 1988-2001 (Albany: SUNY Press, 2012); Ellen Lust-Okar, Structuring Conflict in the Arab World: Incumbents, Opponents, and Institutions, (Cambridge University Press), 2005.
} 
supporting monarchical rule. ${ }^{19}$ Undoubtedly, powerful foreign patrons, geopolitical rents, biased electoral laws and a circumscribed legislative branch are vital to authoritarian persistence. ${ }^{20}$ However, they cannot by themselves explain how Jordan's incumbents continually sidestep demands for political reform. When alternative factors crucial to political outcomes such as religious legitimacy, symbolic power or nationalism are incorporated into analyses, scholars tend to assume or operationalize these "variables" in ways that do not explain or theorize how exactly the monarchy deploys discursive forms of power to legitimate Hashemite rule. ${ }^{21}$ Why so? Until the last decade, attempts among many Middle East specialists to contribute to universal theories and disciplinary debates, 'sovereign structures of scientific knowledge"22 — as Mitchell calls them-led to a far too narrow focus on the institutions of "liberal politics." This resulted in a serious disregard for other modes of governance, participation and resistance, which have been given increasing emphasis since. ${ }^{23}$ Yet still, predominant approaches, especially those prevalent in Jordanian studies, continue to neglect the impact of non-institutional forms of power

\footnotetext{
${ }^{19}$ Anne Marie Baylouny, 'Militarizing welfare: neo-liberalism and Jordanian policy', The Middle East Journal (2008), pp. 277-303; Amaney A. Jamal, Of Empires and Citizens: Pro-American Democracy or No Democracy at All? (Princeton: Princeton University Press, 2012); Sean L. Yom and Mohammad H. Al-Momani. 'The International Dimensions of Authoritarian Regime Stability: Jordan in the Post-Cold War era', Arab Studies Quarterly (2008), pp. 39-60; Anne Mariel Peters and Pete W. Moore, 'Beyond Boom and Bust: External Rents, Durable Authoritarianism, and Institutional Adaptation in the Hashemite Kingdom of Jordan', Studies in Comparative International Development 44.3 (2009), pp. 256-285.

${ }^{20}$ Sean L. Yom and F. Gregory Gause III, 'Resilient Royals: How Arab Monarchies Hang On', Journal of Democracy 23.4 (2012), pp. 74-88.

${ }^{21}$ André Bank, Thomas Richter, and Anna Sunik, 'Long-Term Monarchical Survival in the Middle East: A Configurational Comparison, 1945-2012', Democratization 22 (2015), pp. 179200.

${ }^{22}$ Timothy Mitchell, 'The Middle East in the Past and Future Social Science', in The Politics of Knowledge: Area Studies and the Disciplines, D. L. Szanton, ed. (Berkeley: University of California Press, 2003), p.3.

${ }^{23}$ Michelle Pace and Francesco Cavatorta, 'The Arab Uprisings in Theoretical Perspective-An Introduction', Mediterranean Politics 17.2 (2012), pp. 125-138.
} 
on the political outcomes they are so keen to elucidate. ${ }^{24}$ Authoritarian rule is assumed to arise from the center of a sovereign state controlled by a regime that weaves an all pervasive web of social control, rather than from assorted attempts at administering conduct and molding politics through management, inducement, persuasion and education. $^{25}$ As a result, little attention has been paid to how the monarchy's hegemonic discourse, disseminated through textbooks, speeches, government documents and everyday practices, contributes to the preclusion of consequential political change.

The Palace's own statements make effective political parties appear intrinsic to democratization. ${ }^{26}$ It is political parties' shortcomings and extremist views that make reform at the current conjuncture hazardous. But are political parties even that important? Western-oriented and teleological as it may be, ${ }^{27}$ the democratization literature ascribes to them various roles that are useful to keep in mind. In addition to recruiting and training leaders, organizing the legal opposition and integrating citizens into procedural mechanisms, parties play a key role in institutions and practices deemed crucial to various forms of democracy. ${ }^{28}$ Bartolini and Mair, for example, emphasize their importance for: (1) elections, (2) the organization of factions and interests, (3) parliamentary legislation, (4) formation and appraisal of the executive and (5) policy-

\footnotetext{
${ }^{24}$ Anouar Boukhars, Politics in Morocco: Executive Monarchy and Enlightened Authoritarianism (London: Taylor \& Francis, 2011); Lucas, Institutions and the Politics of Survival; Lust-Okar, Structuring Conflict.

${ }^{25}$ Pascal Debruyne, Spatial Rearticulations of Statehood: Jordan's Geographies of Power Under Globalization (PhD dissertation, Ghent University, 2013).

${ }^{26}$ King Abdullah II, 'Jordan's Security Backbone: Pluralism and National Unity', World Policy Journal 30.3 (September 2013), pp. 31-37.

${ }^{27}$ Thomas Carothers, 'The end of the transition paradigm', Journal of Democracy 13.1 (2002), pp. 5-21; Schwedler, Faith in Moderation, p. 7 and 115-116. For a counter-argument, see Guillermo A O'Donnell, 'In Partial Defense of an "Evanescent Paradigm",' Journal of Democracy 13.3 (2002), pp. 6-12.

${ }^{28}$ Vicky Randall and Lars Svåsand, 'Introduction: The Contribution of Parties to Democracy and Democratic Consolidation', Democratization 9.3 (2002), pp. 1-10.
} 
making. ${ }^{29}$ Others less wedded to liberal iterations of representation argue that parties 'render meaningful the idea of collective rule,' by helping cultivate a broader democratic ethos. ${ }^{30}$ Of course, parties do not always play these roles. Financial fragility, limited linkages with society, a lack of internal democratic procedures, incomplete parliamentarization and clientelism have repeatedly inhibited party development in the Middle East. ${ }^{31}$ These shortcomings have been traced to authoritarian power and its predilections: judiciously-designed electoral systems, powerful patronage linkages, coercive practices or some combination of the above. ${ }^{32}$ Much of this holds true for Jordan, where institutional and distributive mechanisms foster party weakness. What remains far less examined is how the Hashemite regime and the discursive practices it deploys shape the development of Jordan's political parties. Although some may doubt the importance of strong political parties, or the non-institutional forms of power that help maintain them in a position of weakness, the history of Jordanian political reforms makes evident the regime's fear of the former, as well as its astute use of the latter. The Transition to Nowhere: Jordan's Democratic Experiment

In response to a 1988 fiscal crisis and subsequent austerity measures required as part of an IMF structural adjustment program (SAP), Jordanians of various political stripes carried their grievances to the street. Rioting throughout various southern towns

\footnotetext{
${ }^{29}$ Stefano Bartolini and Peter Mair, 'Challenges to Contemporary Political Parties', in Larry Diamond and Richard Gunther, eds., Political Parties and Democracy (Baltimore, The Johns Hopkins University Press), pp. 327- 345.

${ }^{30}$ Jonathan White and Lea Ypi, 'Rethinking the Modern Prince: Partisanship and the Democratic Ethos', Political Studies 58.4 (2010), pp. 810.

${ }^{31}$ Vickie Langohr, 'Too Much Civil Society, Too Little Politics: Egypt and Liberalizing Arab Regimes', Comparative Politics 36.2 (2004), pp. 181-204; Michael J. Willis, 'Political Parties in the Maghrib: The Illusion of Significance?' The Journal of North African Studies 7.2 (2002), pp. $1-22$.

32 Jennifer Gandhi, and Ellen Lust-Okar, 'Elections Under Authoritarianism', Annual Review of Political Science 12 (2009), pp. 403-422.
} 
began on April 17, 1989. The events effectively shattered three decades of martial law, during which most political actors were forced underground or prohibited from framing their programs and activities in terms of the electoral politics that had flourished in the 1950s. ${ }^{33}$ Three months later, King Hussein announced that the regime would hold elections and implement democracy. As various scholars have argued in retrospect, the monarchy's goal was not meaningful participation but stability and control, 'defensive democratization, ${ }^{34}$ through calculated and pre-emptive political liberalization. ${ }^{35}$

Although the 1989 elections were held under the terms of martial law, which banned political parties and placed heavy restrictions on the press, the result was not what the regime expected. The polls returned a boisterous and combative parliamentary majority composed of Islamists and leftists to the re-born Lower House. ${ }^{36}$ The $11^{\text {th }}$ Parliament (1989-1993) presented the monarchy with sincere and serious opposition. Involvement in peace talks with Israel was criticized, as were IMF-backed austerity policies. Although its policy impact was minimal given constitutional constraints on the legislative branch, the $11^{\text {th }}$ Parliament did question, deride and oppose a number of the monarchy's favored policies. ${ }^{37}$ Its vociferousness was cited by various interviewees as one of the main

\footnotetext{
${ }^{33}$ Schwedler, Faith in Moderation, pp. 131-133. For more on political party platforms during the 1950s, see Betty S. Anderson, Nationalist Voices in Jordan: The Street and the State (Austin: University of Texas Press, 2009), pp. 73-74.

${ }^{34}$ Glenn Robinson, 'Defensive Democratization in Jordan', International Journal of Middle East Studies 30 (1998), pp. 387-410.

${ }^{35}$ Lucas, Institutions and the Politics of Survival; Quintan Wiktorowicz, 'The Limits of Democracy in the Middle East: The Case of Jordan', Middle East Journal 53.4 (1999), pp. 606620; Sean L. Yom, 'Jordan: Ten more years of autocracy', Journal of Democracy 20.4 (2009), pp. 151-166.

${ }^{36}$ The elections gave the political opposition a majority of seats (59\%). Islamists took thirty-four seats, leftist candidates won thirteen, independents eleven and regime loyalists held twenty-two.

${ }^{37}$ Jamal al-Rifa'i, 'hịiwār wa munāqasha m'a ra'̄̄s al-wizarā' [Dialogue and Conversation with the Prime Minister], in al-āhzā̄b al-siyāsiyya al-Ūrduniyya: Al-wāq 'a wa al-țmūḥ [Jordanian Political Parties: Aspiration and Reality], (Al-Quds Center for Political Studies, Amman, 2003), p. 18.
} 
reasons for the Palace's quick disenchantment with meaningful political reform. ${ }^{38}$

Following the 1991 National Charter, which bartered social recognition of Hashemite legitimacy for a codified path of political liberalization, the Political Parties and Press and Publications Laws of 1992 were passed. ${ }^{39}$ Although flawed, many hoped their passage would lead to a full-fledged democratic transition. The 1993 elections were to be the first in which parties could campaign legally since their prohibition in 1957 . Yet by the end of the $11^{\text {th }}$ Parliament, the regime realized that public participation in elections did not entail acquiescence. Political liberalization had not been to the monarchy's liking: a last-minute change to the 1986 electoral law in August 1993 ensured that it would be. ${ }^{40}$ The amendment replaced the previous multi-member multi-balloting system with the single non-transferable vote (SNTV). SNTV employs a simple plurality rule in multimember districts, a system that has been described as 'strategically complex, both for voters and candidates. ${ }^{41}$ It incentivizes Jordanian constituents to cast their sole vote on a member of their kin or the tribal elite by localizing elections. As a result, parliamentary candidates consistently avoid party affiliation, as they are deemed hurtful to their electoral prospects. ${ }^{42}$ This directly limits the prospects for national parties. ${ }^{43} \mathrm{~A}$

\footnotetext{
${ }^{38}$ One regime-sponsored account confirms the zeal of Jordan's $11^{\text {th }}$ Parliament, see Aref Muhammad al-Sarhid, al-āmin al-watan̄̄ al-Ūrdun̄̄ wa t'ahadiyyatuhu al-dākhiliyya wa-lkhārijiyya [Jordanian National Security and its External and Internal Challenges] (Șaḥār' Publishing: Amman, 2008), p. 110.

${ }^{39}$ For Jordanian assessments of the emerging party spectrum at the time, see Ahmad Abu Khusa, Al-Dimuqrātiyya wa al-Ahzāb al Siyāsiyya al-Urduniyya [Democracy and Jordanian Political Parties], (Amman: Middle East Publishing Company, 1991); Sashban Khulayfat, Al-dimuqrātiyya fi al-Urdun [Democracy in Jordan], (Amman: Dar Afaq, 1993).

${ }^{40}$ The decree was issued after the dismissal of Parliament. The King invoked an emergency clause in the Constitution knowing full well the objections that would emerge.

${ }^{41}$ John M. Carey and Andrew Reynolds, 'The Impact of Election Systems', Journal of Democracy 22.4 (2011), p. 41.

${ }^{42}$ Interview with Oreib Rentawi (Director of the Al-Quds Center for Political Studies), Amman, Jordan, 3 September 2014.

${ }^{43}$ Lucas, Institutions and the Politics of Survival, pp. 137-156.
} 
second key characteristic of the new electoral system was the purposeful gerrymandering of districts. It favored rural areas and southern towns considered bastions of monarchical support, whom were given a ratio of seats-to-voters far higher than urban areas traditionally linked to opposition currents. ${ }^{44}$ The new electoral formula all but ensured the disproportionate representation of loyalist candidates and affluent tribal leaders invested in the status quo. ${ }^{45}$

Voting patterns in 1993 confirmed the supremacy of geographic considerations and those tied to them: kin, tribe and region. ${ }^{46}$ Palace-designed institutional policies ensured that parliamentary life would re-enforce the logics unleashed at the polls. Stripped of its ability to contest public policies deemed crucial to the monarchy, the Lower House quickly became a crucial $\operatorname{cog}$ in the regime's distribution of patronage to loyal legislators and constituencies. Given budget cuts, fiscal austerity and unequally distributed economic growth, candidates perceived to be capable of channeling funds from a diminishing pool of government resources were increasingly valued.

Parliamentary elections became exercises in 'competitive clientelism,' where nominees vie for access to public resources and to act as intermediaries in patronage networks. ${ }^{47}$ They were a classic example of the 'tragic brilliance' typical of many authoritarian regimes, where citizens' choices are relatively free, 'yet they are constrained by a series of strategic dilemmas that compel them to remain loyal to the regime. ${ }^{48}$

\footnotetext{
${ }^{44}$ Carey and Reynolds, 'The Impact of Election Systems', p. 42.

${ }^{45}$ Yom, 'Ten more years of autocracy', pp. 151-166; Curtis R. Ryan, 'Political Opposition and Reform Coalitions in Jordan', British Journal of Middle Eastern Studies 38.3 (2011), pp. 367390.

${ }^{46}$ Abla M. Amawi, 'The 1993 elections in Jordan', Arab Studies Quarterly 16.3 (1994), p. 18

${ }^{47}$ Ellen Lust, 'Competitive Clientelism in the Middle East', Journal of Democracy 20.3 (2009), pp. 122-135.

${ }^{48}$ Beatriz Magaloni, Voting for Autocracy: Hegemonic Party Survival and its Demise in Mexico
} 
To this day, elections and the parliament they elect remain tightly controlled spectacles designed and closely controlled by the General Intelligence Directorate (GID), the throne's crucial ally and guardian. ${ }^{49}$ Their functions differ decisively from those they pretend to model in more participatory contexts, working instead to co-opt potential opponents, reward loyal supporters and acquiesce the superficial demands of external donors. The electoral law has gone through various iterations since 1993 (2001, 2010, 2012), but its logic remains the same; calculated revisions are meant to 'please international monitors while perpetuating the gerrymandered status quo. ${ }^{50}$ The number of MPs has been increased to 150; 42 electoral districts remain astutely designed and the most recent change went so far as to concede 27 seats to closed proportional national list, so that citizens now cast one vote for an individual candidate and one for a list. ${ }^{51}$ Nevertheless, the $17^{\text {th }}$ Parliament (2013- ), whose election various Jordanian officials treated as 'the inauguration of a new democratic era, ${ }^{52}$ looked very much like its predecessors. Rural governorates dominated by tribal elites and pro-monarchical independents continue to send a disproportionate number of MPs to the legislature, which acts as 'little more than a safety-valve,' willing and able to criticize certain policies, 'but seldom capable of influencing them. ${ }^{53}$ With little incentive to cohere, compete, or even exist, parties remain poorly organized and lacking in programmatic substance, their role

(New York: Cambridge University Press, 2006), p. 19.

${ }^{49}$ Sean L. Yom, 'The New Landscape of Jordanian Politics: Social Opposition, Fiscal Crisis, and the Arab Spring', British Journal of Middle Eastern Studies 42.3 (2015), pp. 286-288.

${ }^{50}$ Ibid., p 288.

${ }^{51}$ For these 27 seats, the country functions as a single electoral district. Interestingly, these electoral lists do not necessarily have to be a political party.

${ }^{52}$ Sean L. Yom, 'Jordan: The Ruse of Reform', Journal of Democracy 24.3 (2013), p. 134.

${ }^{53}$ Mehran Kamrava, 'Frozen Political Liberalization in Jordan: The Consequences for Democracy’, Democratization 5.1 (1998), p. 142. 
in popular mobilization and governance are negligible. ${ }^{54}$ The institutional factors

contributing to this outcome have been laid out above and described better elsewhere.

Equally important but far less examined is the Hashemite regime's portrayal of political parties and its impact on partisan activity in the country.

Producing Weak or Extreme Political Parties

In a September 2013 op-ed in World Policy Journal, King Abdullah II emphasized both the regime's goal, 'effective parliamentary government, under the umbrella of our unifying constitutional monarchy,' as well the 'practical requirements' hindering its development: a lack of 'nation-wide parties, able to formulate programs...party-based parliamentary blocs able to carry through programs and be held accountable by voters. ${ }^{55}$ Of course, party weakness was not linked to practical measures taken by the regime to hinder their development; the blame was placed obliquely but squarely on the shoulders of the citizenry: 'new structures and mind-sets had to be planted deep within our political system,' stated the King. ${ }^{56}$ To disseminate this message, textbooks used in introductory history, civics and politics courses in Jordanian universities reiterate the monarch's perspective. In one broadly used example, democratic reforms are said to require 'sincere affiliation to the homeland, total loyalty to the

\footnotetext{
${ }^{54}$ Interview with Oreib Rentawi (Director of the Al-Quds Center for Political Studies), Amman, Jordan, 3 September 2014.

${ }^{55}$ King Abdullah II, 'Jordan's Security Backbone: Pluralism and National Unity', World Policy Journal 30. 3 (September 2013), pp. 31-37.

${ }^{56} \mathrm{Ibid}$. For an excellent analysis of how the technologies of governance promoted by foreign donors are subtly resisted and re-appropriated by various Arab regimes, see Helle Malmvig, 'Free Us from Power: Governmentality, Counter- conduct, and Simulation in European Democracy and Reform Promotion in the Arab World', International Political Sociology 8.3 (2014), pp. 293-310.
} 
Hashemite regime, respect for the constitution and the law. ${ }^{57}$ Without such principles firmly in place, 'democracy could turn into chaos and an antagonistic slogan that could harm the nation. ${ }^{58}$ For those being introduced to the country's history through sanctioned textbooks, 'Jordan faces a number of internal and external political challenges that constitute elements that threaten its security and political stability. ${ }^{59}$ These hazards 'still overshadow' the transition to democracy. ${ }^{60}$ Such texts depict political parties as potentially threatening given their lack of 'complete loyalty to the Hashemite monarchy. ${ }^{61}$ They are rendered suspect due to their questionable allegiance to the central values of state-sponsored nationalism, which include: deference to the political role and religious legitimacy of the monarchy, the indivisibility of Jordanian national identity (as defined by the regime) and social stability implicitly premised on the suppression of debate regarding sensitive economic and foreign policy issues. ${ }^{62}$ When critiques of the peace treaty with Israel or neoliberal measures are uttered, they are said to reflect merely the 'opposition's desire to criticize every move the country makes. ${ }^{63}$ Democratization is deemed necessary but potential obstacles make a rapid transition appear perilous. Elites promise the eventual inclusion of elected party members in the Cabinet but the King maintains that, 'the timeline for this will depend on our ability to develop effective

\footnotetext{
${ }^{57}$ Ahmad Khalif al-'Afif, Qasem Muhammad Sa'leh, Muhammad Khalil Al-Zaboon, Al-Tarbiyya al-Wataniyya [National Education] (Dar Jarīr, Amman, 2013), p. 215; Jihaad Al-Muwmini, Where to Begin (Amman, 2004), p. 21.

${ }^{58}$ al-'Afif et al. Al-Tarbiyya al-Wataniyya, p. 215.

${ }^{59}$ Ibid., p. 212.

${ }^{60}$ Ibid., p. 215.

${ }^{61}$ Ibid., p. 62.; al-Sarhid, al-ämin al-watanī, pp. 110-117.

${ }^{62}$ Hillel Frisch, 'Fuzzy nationalism: The case of Jordan', Nationalism and Ethnic Politics 8.4 (2002), pp. 86-103; Russell E. Lucas, 'Side Effects of Regime Building in Jordan: The State and the Nation', Civil Wars 10.3 (2008), pp. 281-293; Jillian Schwedler, 'The Political Geography of Protest in Neoliberal Jordan', Middle East Critique 21.3 (2012), pp. 259-270.

${ }^{63}$ al-Sarhid, al-āmin al-watan̄̄, p. 121.
} 
national parties based on platforms. ${ }^{64}$ As one prominent MP remarked in an interview, 'We need real, loyal parties before we embark upon democratic reforms that could be dangerous. ${ }^{65}$ External threats, transferred domestically through political parties, allow authoritarian incumbents to justify repressive censorship laws, restrictions on partisan activities and severe curbs on organized protest. ${ }^{66}$

A favored bogeyman of the monarchy's close allies is the Islamist opposition. While Jordan's Islamist sector is large and influential, it is hardly at the vanguard of radicalism. Most Islamist organizations in the country do not advance a revolutionary Islamic state or even the overthrow of King Abdullah II. The vast majority promote a constitutional monarchy that recognizes the religious legitimacy of the King. But these details are unimportant to regime elites, who continuously demonize the Islamist opposition. Notwithstanding their consistent defense of the monarch's right to reign, Islamist parties and their leaders are consistently described as 'hawkish' ${ }^{67}$ or 'extreme.' 68 In October 2014, former Prime Minister Marouf Bakhit stated that, 'The ideology of the Islamic State is the same as the Muslim Brotherhood. ${ }^{69}$ Of course, only a powerful monarchy can maintain Jordan's religious tolerance and social stability the argument

\footnotetext{
${ }^{64}$ King Abdullah II, 'Each Playing Our Part in a New Democracy', Royal Hashemite Court Discussion Paper, 2 March 2013, available at: http://kingabdullah.jo/index.php/en_US/pages/view/id/249.html (accessed 4 May 2014).

${ }^{65}$ Interview with MP Nayef Leimoun, Amman, Jordan, 18 May 2014.

${ }^{66}$ Mohammed Ali Al Oudat, and Ayman Alshboul, "Jordan First": Tribalism, Nationalism and Legitimacy of Power in Jordan', Intellectual Discourse 18.1 (2010).

67 'Islamists Select Hardliners to Rule Party', Jordan Times, August 16 , 2014.

${ }^{68}$ Mohammed al-D'aemeh, ' $R$ 'aīs wizarā al-Ūrdun al-āsbaq: fikra tanzīm d à esh huwa nafs fikir jimā 'at al-äkhwan al-muslimin' ' [Former Prime Minister of Jordan: The Ideas of the Islamic State in Syria and Iraq are the same as the Muslim Broterhood Society], Al-Sharq al-Awsat, October 20, 2014, http://classic.aawsat.com/details.asp?section $=4 \&$ article $=791424 \&$ issueno=13110\#.VLF8Bo5qE2 $\underline{0}$ (accessed 10 November 2014).

${ }^{69}$ Ibid.
} 
goes; an Islamist victory would impose a dangerous form of theocratic tyranny. ${ }^{70}$

The monarchy and its allies' portrayal of partisan life is flexible. Depending on the audience, political parties are deemed inept, ineffective or dangerous. At a November 2013 conference on political participation jointly organized by the $\mathrm{Al} \mathrm{Ra}$ ' $\mathrm{i}$ Center for Research and Institut Francais, Amman Mayor Aqel Biltaji reminded the audience that 'the political party system has not yet materialized in Jordan; they have not developed a clear vision with a tangible roadmap of the goals they seek to achieve. ${ }^{71}$ While participating in a workshop run by foreign NGOs in January 2014, one MP asserted in an interview that, 'party leaders should take Introductory Economics before we even think about changing the electoral law. ${ }^{72}$ When pushed on the undemocratic nature of his remarks, the MP mentioned the Muslim Brotherhood's brief tenure in power in neighboring Egypt, 'Look what happened under Morsi, the Islamists have no idea how to govern or run an economy. ${ }^{, 73}$ Others, such as Dr. Rohil Gharaibeh, a former member of the Islamic Action Front (IAF) and prominent participant in the reformist ZamZam Initiative, stress long-standing links between foreign organizations and Jordanian parties to explain the latter's weakness. ${ }^{74}$

In Jordan we suffer from a unique problem, an essential difference (al-fāriq aljawharī). All parties have a foreign reference. In Morocco, there are truly Moroccan parties. They may be similar to or draw on the ideology of foreign

\footnotetext{
${ }^{70}$ Tamer al-Samadi, 'Abdullah al-thani yuhadhir min diktatoriyat diniyyah' [King Abdullah warns of religious dictatorships], Al-Hayat, January, 132013.

${ }^{71}$ Gaelle Sundelin, 'Political parties need clear framework to grow', Jordan Times, November 13, 2013, available at: http://jordantimes.com/political-parties-need-clear-legal-framework-to-grow---activists (accessed 9 May 2014).

${ }^{72}$ Interview with MP Abdul Hadi al-Majali (President of the National Current Party), Amman, Jordan, 18 January 2014.

${ }^{73}$ Ibid.

${ }^{74}$ Interview with Dr. Rohil Gharaibeh (Manager of Al-Umma for Studies and Research and member of the ZamZam Initiative), Amman, Jordan, 4 September 2014.
} 
organizations like the Muslim Brotherhood or PLO but in Jordan we are wholly dependent on them.

For Gharaibeh, critical of the Hashemite regime on various fronts, this foreign influence leads to a lack of national policies amongst the country's political organizations: 'Jordanian issues receive little attention in party platforms and speeches, while Palestine, occupation and Iraq always garner large protests and media attention., ${ }^{75}$

The perceived dependence of Jordanian political parties on foreign organizations, accusations of which date back to the spread of Pan-Arabist currents in the 1950s, allows the regime to repress or de-legitimize parties by highlighting their foreign ties or supposed disinterest in national issues. For example, during the 1996 bread riots in Karak, King Hussein accused Iraq and several pro-Iraqi leftist parties of fomenting social unrest in the city before ruthlessly repressing protestors. ${ }^{76}$ Rather than legitimate grievances related to increases in the cost of living or inequality, social unrest and public protest is frequently depicted as the product of irresponsible political organizations linked to dangerous outside forces. Ties to foreign parties and movements are disconnected from the political measures that have historically made them useful or necessary: martial law, a lack of incentives for nationally-based platforms and the regime's own conservative nationalism. Instead, it is blamed upon the extremist beliefs or administrative incapacities of political organizations. As one textbook asserts, 'most left-wing and regionally-linked parties work to inflate the size of doubts around national belonging...they want to take internal divisions to an extreme. ${ }^{, 77}$ Many citizens disbelieve or actively resist these claims; various surveys confirm widespread disenchantment with the pace of political

\footnotetext{
${ }^{75}$ Ibid.

${ }^{76}$ Lamis Andoni and Jillian Schwedler, 'Bread riots in Jordan', Middle East Report 201 (1996), pp. $40-42$.

${ }^{77}$ al-Sarhid, al-ämin al-watan̄i, p. 85.
} 
reform. ${ }^{78}$ In private conversations and internal party meetings, ample opposition to Palace-sponsored portrayals of political parties was expressed. Yet the reiteration of the monarchy's preferred tropes in the public sphere occasions demonstrations of external compliance, which re-enforce a web of meanings central to the regime's hegemony. ${ }^{79}$ How exactly one can oppose the monarchy's preferred policies without succumbing to the regime's definition of key nodal points or being accused of treason is a vexing question.

In an interview with local daily al-Ghad in August 2014, King Abdullah II revived this age-old strategy. He ascribed frequent bouts of unrest in the southern city of Ma'an to, 'a small, limited group of outlaws who do not represent [the town's inhabitants],' just as military forces were called in to repress growing protests. ${ }^{80}$ For Mohammad Farghal, director general of the Center for Strategic Studies at Jordan's premier defense academy and a retired major general in the country's armed forces, the solution to such social unrest lies not in democratization or broadening participation but in 'economic development and a careful eye towards those external forces fueling social unrest by way of our underdeveloped political organizations. ${ }^{, 81}$ For Interior Minister

\footnotetext{
${ }^{78}$ Al Hayat Center for Civil Society Development, 'A Study Investigating the Trends within the Jordanian Society Regarding Political Parties, Political Knowledge, and Participation in the Elections', March 2013, http://www.hayatcenter.org/uploads/2015/02/20150209164614en.pdf. University of Jordan, Center for Strategic Studies, 'The State of Democracy in Jordan, Public Opinion Survey', 18 January 2012, http://www.jcss.org/ShowNews.aspx?NewsId=317\#.VLEpo5qE20

${ }^{79}$ Lisa Wedeen, Peripheral Visions: Publics, Power, and Performance in Yemen. (Chicago: University of Chicago Press, 2009), pp. 63-66.

${ }^{80}$ Jumana Ghneimat, 'Interview with his Majesty King Abdullah II', Al Ghad, August 10, 2014, p. 1

${ }^{81}$ Interview, Amman, Jordan, 25 April 2014.
} 
Hussein al-Majali, who later resigned due to his mishandling of the unrest in $\mathrm{Ma}^{\text {'an }}{ }^{82}$ the rioters who attacked a host of government facilities 'were outlaws and wanted individuals. These are not loyal Jordanian citizens but criminals who are often fuelled by foreign ideologies, funds and organizations. ${ }^{83}$ Well-known for his hard-handed approach to public protests as well as his consistent threats to disrupt the IAF's peaceful political rallies, al-Majali explains social unrest by blaming 'outside forces, which use Jordanian organizations to further their objectives. ${ }^{84}$ Again, this trope is present in one of the country's civics textbooks: 'The foreign links of most parties raises doubts about their integrity, goals and principles, as well as the extent of their belonging to the nation. ${ }^{85}$ The lack of institutionalized forums in which to express disagreement, register protest or impact policies that have exacerbated social inequality play no apparent role. Popular unrest is more easily ascribed to political parties, who through their extremism or weakness become the vector for external threats.

Reproducing Hashemite Tropes: Jordan's Self-Fulfilling Prophecy

Given the regime's long history of controlled political life, neither the monarchy nor Farghal or al-Majali's remarks should be all that surprising. What is far more interesting is how Dr. Gharaibeh, local activists and members of civil society adopt or reproduce regime-sponsored critiques of Jordanian parties that help legitimize the current 'façade democracy. ${ }^{86}$ For the head of the University of Jordan's Center of Strategic

\footnotetext{
${ }^{82}$ Suleiman al-Khalidi 'Jordan's Interior Minister Resigns, Police Chiefs Dimissed', Reuters May 17, 2015, http://www.reuters.com/article/2015/05/17/us-jordan-police-ministeridUSKBN0O20SU20150517 (accessed 20 May 2015).

${ }^{83}$ Interview, Amman, Jordan, 7 May 2014.

${ }^{84}$ Ibid.

${ }^{85}$ al-Sarhid, al-āmin al-watan̄̄, p. 123.

${ }^{86}$ Beverley Milton-Edwards, 'Façade Democracy and Jordan', British Journal of Middle East Studies 20 (1993), pp. 191-203.
} 
Studies, Musa Shteiwi, 'Political parties in Jordan are not fit for a democratic transition. ${ }^{, 87}$ He describes them as ill prepared and with little commitment to public participation. Although critical of the government on various fronts, Professor Shteiwi condemns parties for, 'having grand ideals but no real programs, I have no faith in any of them. ${ }^{88}$ Similarly, numerous local activists and non-affiliated critics of the regime described political parties as inept or incapable. ${ }^{89} \mathrm{~A}$ local journalist, who was highly critical of the Palace's foreign policy similarly argued that, 'Parties do not offer concrete solutions and programs, we are better served by the King and his advisors. ${ }^{90}$ One prominent member of the tribal hirāk (movement) described his disinterest in party life by way of their ineffectiveness, 'There is no point in joining them [political parties] since they get nothing done. Imagine what an executive branch composed of those amateurs would do to the country.",91

The impact of the monarchy's rhetoric lies not just in the intentions of those who formulate it but in 'the conditions of their manifest appearance,' as well as the 'transformation which they have effected.' 92 Stripped of alternative vocabularies or imaginaries through which to explain democratization's delay, the onus must fall on the political parties the regime has always blamed. As one would expect, government elites highly dependent on the Palace's support claim they have no choice, responding as they

\footnotetext{
${ }^{87}$ Interview, Amman, Jordan, 16 April 2014.

${ }^{88}$ Ibid.

${ }^{89}$ Interview with anonymous Jordanian lawyer and human-rights activist, Amman, Jordan, 10 April 2014; Interview with Dr. Sami Hourani (Executive Director, Leaders of Tomorrow), Amman, Jordan, 15 July 2014.

${ }^{90}$ Interview with Raed Omari (Journalist on Political Affairs desk for The Jordan Times and AlArabiya), Amman, Jordan, 4 June 2014.

${ }^{91}$ Confidential Interview with hirāk activist, Amman, Jordan 27 March 2014.

${ }^{92}$ Lisa Wedeen, Ambiguities of Domination: Politics, Rhetoric, and Symbols in Contemporary Syria (Chicago: University of Chicago Press, 1999), p. 153.
} 
are to the barrenness of parliamentary and political life. ${ }^{93}$ 'Reform needs to be gradual,' one former Minister and current Senator repeated, 'we lack true democrats, the opposition is filled with opportunists who only want to seize power. ${ }^{, 94}$ Yet crucially, such assertions are not limited to monarchy's most strident allies and supporters. In more than 100 interviews with civil society representatives, foreign and local NGOs, journalists, academics and various individuals (students, businessman, bakers) critical of the regime's democratization efforts, the immaturity or zealotry of those striving to mobilize the local electorate was continually emphasized. Of course, there were important differences in their remarks, often about who was to blame for the current political state of affairs (United States, Israel, tribal conservatives, the GID and Armed Forces). Yet their statements regarding political parties, especially when conducted in on-the-record interviews or made in public forums, displayed unforeseen levels of agreement.

For Dr. Amer Beni Amer, director of the non-profit Al Hayat Center for Civil Society Development, "parties are not doing a good job of representing the people. ${ }^{95}$ While cognizant of the various obstacles hindering party growth, especially the electoral law, Amer de-historicizes the reasons for their weakness when describing their current role: 'At the moment they are nothing but decoration, people want them [political parties] to show they are serious, which they have yet to prove. ${ }^{96}$ Similar assertions were made in the majority of interviews with other Jordanian NGOs concerned with constitutional and political issues. The electoral law was occasionally criticized, political reform was

\footnotetext{
${ }^{93}$ For one well-known example, see King Abdullah II's interview with Jeffrey Goldberg, "The Modern King in the Arab Spring," The Atlantic, April 2013.

${ }^{94}$ Interview with Senator Hani Mulqi, Amman, Jordan 4 May 2014. Mulqi has since been appointed as Commissioner of the Aqaba Special Economic Zone.

${ }^{95}$ Interview with Dr. Amer Bani Amer (Founder and Director, Al Hayat Center for Civil Society Development-RASED), Amman, Jordan, 1 September 2014.

${ }^{96}$ Ibid.
} 
frequently deemed necessary and partisan life described as essential to democratization.

Yet political parties were consistently described as weak, incapable or extreme. Crucially, the monarchy was never described as a hindrance to democratization, but positioned instead 'at the forefront of reform. ${ }^{97}$

Similar accounts were advanced by a host of non-Jordanian NGOs. While the foreign donor community encompasses a diverse array of actors, most organizations prefer to sustain themselves by depoliticizing their interventions and programs. Unsurprisingly, they faithfully reproduce regime narratives regarding political parties. For example, in 2003, the International Crisis Group noted that Jordan's parties are 'institutional and financially weak,' they are not only poorly organized internally but 'lack defined agendas and suffer from a deficit in grassroots support.' They are content with 'vacuous slogans and unrealistic proposals,' moreover, 'shortcomings within the parties themselves are largely to blame for this weakness. ${ }^{, 98}$ More recently, the US government-funded National Democratic Institute (NDI) argued in its 2010 election report that 'parties center more on individual leaders and personalities than on political platforms or ideologies. ${ }^{99}$ Even when such organizations mention the institutional factors hindering party development, they rarely connect such outcomes to the regime's discursive practices, or the foreign assistance that helps make Jordan's political status quo possible. ${ }^{100}$

\footnotetext{
97 Ibid.

${ }^{98}$ International Crisis Group, 'The Challenge of Political Reform: Jordanian Democratisation and Regional Instability', Middle East Briefing, Amman/Brussels, 8 October 2003, p. 1 and 19.

${ }^{99} \mathrm{https} / / / \mathrm{www}$. ndi.org/files/Jordan-International-Election-Report-2010-ENG.pdf

${ }^{100}$ Since the onset of the Arab Spring, the United States Congress has reiterated on various occasions that Jordan's $\$ 660$ million annual aid package would remain steady due to the country's strategic value. In January 2016, Congress passed 'an unprecedented' \$1.275 billion in
} 
The most recent USAID Country Development Cooperation Strategy (2013-2017) for Jordan exemplifies these twisted logics. After highlighting how 'Jordan's civil society is nascent,' and its 'political parties are also weak,' the strategy document outlines a number of programs aimed at strengthening 'political participation and accountability.' 101 These focus on assistance to civil society organizations, prioritizing improvements in service delivery, advocacy skills and organizational management. Despite their obsession with bolstering parties through "capacity building," "legislative strengthening," "youth engagement" and other ambiguous "slogans," most politically-oriented NGOs neglect the larger issues and actors inhibiting party development and political reform. Aid or loans from the US or the Gulf Cooperation Council (GCC) that sustain the political status-quo are never mentioned, it is simply assumed that the regime 'will maintain broad political will,' to pursue the policies necessary for 'political stability.' ${ }^{102}$ By reproducing the regime's narrative, these organizations, as well as the monarchy's foreign allies, ${ }^{103}$ erase popular grievances and politics from the democratization debate. Democracy becomes an abstract value to be achieved, rather than a contested political outcome; a moral category that concerns social attitudes and values rather than tangible political processes. This contributes to a very rigid and controlled engagement with questions of public participation. It sidelines alternative practices and interpretations of democracy while giving the impression of a nascent transition for consumption by their benefactors.

assistance in the country's 2016 budget. 'Congress approves "unprecedented" assistance to Jordan-Wells', Jordan Times, 21 January 2016.

${ }^{101}$ USAID, 'Jordan: Country Development Cooperation Strategy (2013-2017)', p.8 https://www.usaid.gov/sites/default/files/documents/1883/CDCSJordan.pdf (accessed 8 June 2014).

102 Ibid., p. 27.

${ }^{103}$ For an excellent example of such rhetoric amongst the Washington foreign policy establishment, see Robert Satloff and David Schenker, 'Political Instability in Jordan', Contingency Planning Memorandum No. 19, Council on Foreign Relations Press (May 2013). 
Political party members are neither blind to the regime's discursive practices nor unaware of their impact on partisan activity. For Ablah Abu Obleh, MP for Amman and Secretary General of the Jordanian Democratic People's Party (HASHD): 'The electoral law makes our efforts to gain supporters in Jordanian society difficult, but this is not the whole story. People are afraid of joining political parties, memories of the martial law period still weigh heavily on society. ${ }^{104}$ After outlining the various measures HASHD has taken to counter popular trepidations (educational workshops, a weekly magazine, participation in elections), Abu Obleh revisited the difficulties fostered by the discursive panorama: 'The security apparatus controls the conversation, it establishes the outlines of political life. Parliament can change certain laws, but partisan activity will be largely unimportant until political parties are no longer described or thought of as threats to social stability. ${ }^{105}$ At a conference organized by the Al-Quds Center for Political Studies in September 2014, Sheikh Hamza Mansour, then Secretary General of the Islamic Action Front (IAF) ${ }^{106}$ vociferously condemned the electoral law as 'a sanctions law rather than a freedom law, a crucial obstacle to parliamentary government.' Yet Mansour's disdain, and that of various interviewed members of the Muslim Brotherhood's political arm in Jordan, extends far beyond this one piece of legislation.

Reforming the media and the political parties law are also essential. There is currently no space for parties to organize or recruit potential members or spread their ideologies. The people have been told to fear or ignore us. The King's vision of strong partisan life will be impossible until we are given the space to openly recruit and actively mobilize citizens, without us or them fearing repercussions. ${ }^{107}$

\footnotetext{
${ }^{104}$ Interview with MP Ablah Abu Obleh Amman, Jordan, 29 May 2014.

${ }^{105}$ Ibid.

${ }^{106}$ Mansour has since been replaced by Sheikh Hammam Said.

${ }^{107}$ Al-Quds Center for Political Studies Conference, 'The Constitutional Amendments and Parliamentary Government', 6 September 2014, Landmark Hotel, Amman.
} 
In private conversations, active members of Jordanian political parties consistently described the numerous hindrances to the development of their organizations. The electoral law was frequently given pride of place, but the reputation of political parties, their portrayal in the media, was never far behind in their list of concerns. Participants in partisan life lacked neither agency nor opinion, merely the institutional tools, symbolic resources and social capital through which to alter the discursive status quo.

Through textbooks, speeches, and the repetition of certain tropes in widely accessible venues (radio, newspapers, television broadcasts), the monarchy has made its preferred vision of democracy, the opposition and political reform pervasive. ${ }^{108}$ Such narratives operate as forms of power and influence in their own right, shaping political debates and sustaining the discursive conditions through which the regime bolsters its hegemony. ${ }^{109}$ Of course, this public transcript does not tell the whole story. Despite their current predominance, the regime's preferred narratives are not ubiquitous, nor believed by all. When asked about the impact of the electoral law, patronage practices and other structural factors on Jordanian politics, one student at the University of Jordan stated:

If it were just about institutions and their manipulation, political life and opposition would look very different. We have been contesting the electoral law since 1993. The real problem is how the regime controls the conversation; this is why popular unrest rarely translates into a pro-democracy movement. ${ }^{110}$

Like any political community, Jordan's authoritarian incumbents offer justifications for the exercise of power so as to win popular consent for institutional arrangements and government policies. They dominate what remains a lopsided discussion, deploying a highly partial and self-serving set of narratives that are "designed to be impressive, to

${ }^{108}$ Betty S Anderson, 'Writing the Nation: Textbooks of the Hashemite Kingdom of Jordan', Comparative Studies of South Asia, Africa and the Middle East 21.1 (2001), pp. 5-14.

${ }^{109}$ Wedeen, Ambiguities of Domination, p. 5.

${ }^{110}$ Confidential Interview, Amman, Jordan, 14 June 2014. 
affirm and naturalize the power of dominant elites, and to conceal or euphemize the dirty linen of their rule." ${ }^{111}$ While this paper is limited to analyzing the dissemination and impact of the monarchy's preferred narratives, I wish to emphasize that in Jordan, as in other locales, discursive forms of power are far from all-determining. Ordinary citizens are not merely 'the playthings of elite discourse. ${ }^{, 112}$ But appearances do matter, and even false deference is an important exhibition of the regime's grip on politics. The capacity of dominant groups to prevail—although never completely—in constituting the public transcript is both a key instrument and measure of their power. ${ }^{113}$

\section{Jordan's Self-Fulfilling Prophecy}

Seen from afar, Jordan's democratic transition appears to be underway. But a closer look takes much of the shine off of the regime's reformist veneer. The Hashemite Kingdom retains certain formally democratic institutions and procedures, yet the underlying distribution of power remains far from democratic. Despite the selective implementation of reforms since 2011, the country's Constitution, especially articles 24 30, still retains explicitly autocratic features. The fundamental powers of government remain subject to the whims of one man; yet importantly, the majority of those who dare speak out are not ruthlessly crushed, but steadily suffocated. Key to this asphyxiation is the simultaneous deployment of the rhetoric of democratization alongside its subversion from within. The monarchy and its allies regularly espouse their desire to initiate and carry out a transition, yet continually emphasize various factors (regional instability, the

\footnotetext{
111 James C. Scott, Domination and the Arts of Resistance: Hidden Transcripts (New Haven: Yale University Press, 1990), p. 18.

${ }^{112}$ John Chalcraft, 'Egypt's 25 January Uprising, Hegemonic Contestation, and the Explosion of the Poor', The New Middle East: Protest and Revolution in the Arab World, Fawaz A. Gerges ed. (Cambridge, UK, Cambridge University Press, 2014) p. 179.

${ }^{113}$ Scott, Domination and the Arts of Resistance, p. 14 and 50.
} 
citizenry's immaturity, political party extremism or incapacity) that hinder the process. The efficacy of the regime's preferred categories can be glimpsed in the ways that their repetition helps bring into being the reality it presumably only describes, producing observable political effects. ${ }^{114}$ 'Of course we are weak,' PFLP General Secretary Abu Obleh argued, 'if powerful people call someone crazy enough times, everyone will believe it, or at least pretend to. ${ }^{115}$ Defeated institutionally and degraded rhetorically, political parties in the country look just as those in power describe them.

Party weakness is, in many respects, a self-fulfilling prophecy, what sociologist Robert K. Merton defines as, 'in the beginning, a false definition of the situation evoking a new behavior which makes the original false conception come "true"., 116 As Merton reminds us: 'The specious validity of the self-fulfilling prophecy perpetuates a reign of error, ${ }^{117}$ more than two decades after liberalization began, Jordanian parties remain poorly organized and meekly supported. The 'real challenge facing the opposition today is voters' reluctance to join political parties, ${ }^{118}$ claims King Abdullah II, altering the behavior of the more than $90 \%$ of Jordanians who do not join organized parties is 'a matter that requires serious efforts." ${ }^{, 19}$ 'For the prophet will cite the actual course of events as proof that he was right from the very beginning': when parties boycott

\footnotetext{
${ }^{114}$ Wedeen, Peripheral Visions, pp. 8-18.

${ }^{115}$ Interview with MP Ablah Abu Obleh Amman, Jordan, 29 May 2014.

${ }^{116}$ Robert King Merton, Social Theory and Social Structure (New York: The Free Press, 1968), p. 477.

${ }^{117}$ Ibid.

${ }^{118}$ Ibid.

${ }^{119}$ Samir Hiyari and Samir Barhoum, 'Interview with his Majesty King Abdullah', Al-Rai, December 5, 2012, translation can be found at:

http://www.kingabdullah.jo/index.php/en_US/interviews/view/id/501/videoDisplay/0.html
} 
elections, play little legislative role or perform poorly in the polls, the monarchy's prophecy stands confirmed. ${ }^{120}$

\section{Conclusion}

In an attempt to further the post-democratization research agenda, this article has examined the complex interrelation between knowledge production, discursive practices and political outcomes. By way of semi-structured interviews with political elites, participant observation at party meetings and NGO conferences and close analysis of textbooks, speeches and official Palace documents, it dissects an all too often overlooked aspect contributing to party weakness: how the Hashemite regime's portrayal of Jordan's political parties relates to their very existence. I argue that state-sponsored articulatory practices contribute to the discrediting of potential opponents, a contingent and contested process that undermines public participation, and is by no means unique to Jordan. Far too frequently, an over-reliance on institutional approaches focused on rents, access to power and constitutional design blur micro-dynamics crucial to authoritarianism. ${ }^{121}$ Analysts commit what Antonio Gramsci regarded as the most pervasive error in politics: equating state power with the formal institutional apparatus. ${ }^{122}$ When academic inquiries restrict themselves to these institutional confines, scholars risk missing out on a range of subtle mechanisms and shifting techniques of governance through which authoritarian rule is crafted, resisted and reproduced.

In Jordan, authoritarian incumbents have put considerable effort into defining and

\footnotetext{
${ }^{120}$ Merton, Social Theory, p. 477.

${ }^{121}$ Martin Beck and Simone Hüser, 'Jordan and the 'Arab Spring': No Challenge, No Change?' Middle East Critique 24.1 (2015), pp. 83-97.

${ }^{122}$ Gramsci, Selections from the Prison Notebooks, p. 89.
} 
circulating representations of the nation-state and Jordanian politics. ${ }^{123}$ They deploy their 'paradigm power' over the discursive space so as to maintain their position by making certain concepts and histories meaningful and acceptable to the citizenry. ${ }^{124}$ When key voices position the monarchy as the source of democratic reforms and portray the organized opposition as incapable, dangerous or immature, a distinct field of politics is formed and delimited. As a result, Jordanians become less susceptible to alternative and oppositional discourses, which also become harder to formulate. Of course, no one actor can completely dominate a field of discursivity, and the Palace's preferred narratives are intermittently subject to various forms of resistance. ${ }^{125}$ Nevertheless, the Hashemite regime can be said to have created a hegemonic formation by constructing 'not a shared ideology but a common material and meaningful framework for living through, talking about, and acting upon social orders characterized by domination. ${ }^{, 126}$ This is a subtle but crucial mechanism for the reproduction of authoritarian power. It not only ensures support and funds from foreign donors, but also generates a politics of partial dissimulation that works to induce complicity and enforce obedience amongst the

${ }^{123}$ Layne, Linda L. Home and Homeland: The Dialogics of Tribal and National Identities in Jordan (Princeton: Princeton University Press, 1994); Joseph Andoni Massad, Colonial Effects: The Making of National Identity in Jordan. (New York: Columbia University Press, 2001).

${ }^{124}$ Asef Bayat, Life as Politics: How Ordinary People Change the Middle East (Stanford University Press, 2013), p. 155.

${ }^{125}$ For two excellent examples related to political parties, see 'tawșiyyāt lajina al al-āḥzāb alsiyāsiyya [Recommendations of the Political Party Committee],' pp. 211-220, in al-āh $\bar{h} z \bar{a} b$ alsiyāsiyya al-Ūrduniyya: Al-wāq'a wa al-țumūh [Political Parties in Jordan: Reality and Aspitation], (Al-Quds Center for Political Studies, Amman, 2003) and Al-quwānīn al-nāzima lil 'aml al-hizbī fi-l-Ürdun [Political party Legislation in Jordan],' (Al Quds Center for Political Studies, Amman, 2010).

${ }^{126}$ William Rosebery, 'Hegemony and the Language of Contention', in Everyday Forms of State Formation: Revolution and the Negotiation of Rule in Modern Mexico, ed. Gilbert Joseph and Daniel Nugent (Durham: Duke University Press, 1994), p. 361. 
citizenry. ${ }^{127}$ It does so through repetition and calculated enforcement, draining citizens' political energies and habituating them to formulaic and self-serving rhetoric that fosters their accommodation with authoritarian power's hard realities. As Lisa Wedeen has argued in the case of the Assad cult in Syria, official rhetoric, images and narratives not only exemplify a given political order's power, they also help produce it. ${ }^{128}$ This is why the monarchy and its allies fill, with symbolic display and rhetorical flourish, the considerable chasm between the recalcitrant authoritarian realities of contemporary Jordan and the promise of the regime's self-proclaimed democratizing pretensions.

For monarchical rule to persist without the constant use or threat of coercion, the Hashemite regime must depend on more than brute force and institutional manipulation. For its hegemonic practices to "work," the Palace must diffuse particular views and concepts throughout society. By partially fixing conceptions of democracy, reform and political parties, the Hashemite monarchy legitimizes certain governance techniques and practices. This is but one small part of the larger project through which ruling elites articulate different identities and subjectivities into a common project of rule. Crucially, this dynamic process cannot be fully understood without recourse to an analysis of discursive practices that remains sensitive to the institutions and relations of force that structure the field of knowledge. While it remains true that the political economy excludes the poor from prosperity, it is through close attention to the Hashemite regime's discursive practices that we can observe how they are eased out of representation. ${ }^{129}$ Authoritarian persistence in Jordan cannot be understood or explained in isolation of such

${ }^{127}$ Lisa Wedeen, 'Conceptualizing Culture: Possibilities for Political Science', American Political Science Review 96.04 (2002), pp. 713-728.

${ }^{128}$ Lisa Wedeen, Ambiguities of Domination.

${ }^{129}$ Michael MacDonald, Why Race Matters in South Africa (Cambridge: Harvard University Press, 2006). 
powerful techniques of rule. 